\title{
Correction to: Child Psychological Adjustment to War and Displacement: A Discriminant Analysis of Resilience and Trauma in Syrian Refugee Children
}

\author{
Guido Veronese $\mathbb{B}^{1} \cdot$ Alessandro Pepe ${ }^{1} \cdot$ Francesca Giordano $^{2}$
}

Published online: 21 October 2021

(c) The Author(s) 2021

Correction to: Journal of Child and Family Studies (2021) 30:2575-2588

https://doi.org/10.1007/s10826-021-02067-2

The original version of this article unfortunately contained a mistake. The given names and family names of the authors were interchanged. The correct author names are Guido Veronese, Alessandro Pepe, and Francesca Giordano. The original article has been corrected.
Open Access This article is licensed under a Creative Commons Attribution 4.0 International License, which permits use, sharing, adaptation, distribution and reproduction in any medium or format, as long as you give appropriate credit to the original author(s) and the source, provide a link to the Creative Commons license, and indicate if changes were made. The images or other third party material in this article are included in the article's Creative Commons license, unless indicated otherwise in a credit line to the material. If material is not included in the article's Creative Commons license and your intended use is not permitted by statutory regulation or exceeds the permitted use, you will need to obtain permission directly from the copyright holder. To view a copy of this license, visit http://creativecommons.org/licenses/by/4.0/.

The original article can be found online at https://doi.org/10.1007/ s10826-021-02067-2.

Guido Veronese

guido.veronese@unimib.it

1 "R. Massa" Department of Human Sciences and Education, University of Milano-Bicocca, Milano, Italy

2 Department of Psychology, Università Cattolica del Sacro Cuore, Milano, Italy 